\title{
Planning and Development Strategy of Fishery Product Processing Business Based on Pesantren
}

\author{
Ramli $^{1}$, Budi Setiawan ${ }^{2}$, Imam Santoso ${ }^{3}$, Siti Asmaul Mustaniroh ${ }^{4}$ \\ \{ramliarul80@gmail.com¹, budis13@yahoo.com², imamsantoso@ub.ac.id ${ }^{3}$, asmaul_m@yahoo.com $\left.{ }^{4}\right\}$ \\ Department of Fisheries Product Technology, Ibrahimy University, Indonesia ${ }^{1}$ \\ Department of Agricultural Economics Social, Brawijaya University, Indonesia ${ }^{2}$ \\ Department of Agricultural Industry Engineering, Brawijaya University, Indonesia ${ }^{3}$ \\ Department of Agricultural Industry Engineering, Brawijaya University, Indonesia ${ }^{4}$
}

\begin{abstract}
This study aims to determine the planning and development strategy of fishery product processing business based on pesantren at Situbondo Regency. The method used in determining the strategy is SWOT and QSPM methods. The results showed that alternative strategies based on the priority scale included (1) improving the quality of pesantren human resources, (2) improving the system and management of pesantren organization, (3) managing the market potential of pesantren, (4) developing the system of fishery product processing business is professionally, (5) developing the fishery processed products is superior based on pesantren, (6) strengthing the character and adaptability of pesantren, (7) improving the institutional performance of pesantren, (8) Building the cooperation access, (9) developing the system of sustainable fishery product processing business.
\end{abstract}

Keywords: fishery product processing business, pesantren, planning, and development strategy, SWOT, QSPM

\section{Introduction}

Situbondo Regency East Java Province has great potential in the fishery sector. The total coastline is $\pm 155 \mathrm{~km}$. The fishery production of capture and aquaculture in 2017 was 13,146 tons and 6,330 tons [1]. The great potential of the fishery sector must be realized into kinetic energy so the fishery development goal at Situbondo Regency can be achieved. One of the efforts can be done through fishery product processing business [2].

Planning and development of fishery product processing businesses require selection of commodity priorities, location suitability, and fishery products processing patterns [3]. Thus the planning and development of fishery product processing businesses at Situbondo Regency can be done based on pesantren because there are hundred of pesantren at Situbondo Regency. Pesantren (Islamic boarding school) is the oldest education system today when compared to educational institutions that have appeared in Indonesia and have long been regarded as products of Indonesian culture with distinctive character [4]. Based on the pesantren database at the Religion Ministry office, 180 pesantren with tens of thousands santri (students) are at Situbondo Regency.

Planning and development of fishery product processing businesses based on pesantren are believed to have good prospects because pesantren have great social capital through kyai 
(pesantren leaders) as central figures of pesantren. Social capital can be converted into economic value [5]. However, the kyai social capital is great made the dependence of pesantren on kyai is high relatively, which had a negative impact on the pesantren organization system [6].

Based on the description is above, planning and development strategy of fishery product processing businesses based on pesantren in Situbondo Regency is needed. Planning and development strategy will help stakeholders, especially local government and kyai as pesantren leaders, to make the right decisions. Research on planning and development strategy of fishery product processing businesses has been carried out by [7], [8], [9], [10], [11], [12]

\section{Methods}

The SWOT method is used to identify and evaluate internal and external factors, which are based on logic to maximize Strengths and Opportunities and to minimize Weaknesses and Threats. The Quantitative Strategic Planning Matrix (QSPM) method is a tool to evaluate the strategies to be implemented to optimize the results obtained. QSPM is a recommended tool by experts to evaluate the alternative strategy choices is objectively.

The study was conducted on the pesantren at Situbondo Regency, East Java, from January to April 2018. The method of data collection is done by: (1) literature study, (2) field observations, and (3) in-depth interviews with 25 respondents.

The steps of SWOT analysis are follows:

1. Analyze the factors of internal (strengths and weaknesses) and externals (opportunities and threats)

2. Determining the organization position in the SWOT quadrant.

3. Formulating the organizational strategies based on the analysis results of all factors of internal and external.

The steps of QSPM are follows:

1. Making the list of internal and external factors is taken directly from the SWOT matrix.

2. Providing the weights for each internal and external factors. This weight must be identical to the weight given in the internal and external factors analysis on the SWOT matrix

3. Writing the alternative strategies taken from the SWOT matrix.

4. If the factors have an effect on the alternative strategies being considered, give the value of AS (Attractiveness Score) that ranges are 1 to $4,1=$ not attractive, $2=$ rather attractive, 3 $=$ attractive and $4=$ very attractive.

5. Calculating the Total Atractiveness Score (TAS) by multiplying the weight with Atractiveness Score (AS).

6. Calculating the total value of TAS in each QSPM column. The largest TAS value indicates that the alternative strategy is the first choice and the smallest TAS value indicates that alternative strategy is the last chosen. 


\section{Results and Discussion}

\subsection{SWOT analysis}

\section{Internal and external factors analysis}

The analysis results of internal and external factors on the planning and development of fishery product processing business based on pesantren at Situbondo Regency can be seen in Table 1 and Table 2

Table 1. Internal factors analysis on the planning and development of fishery product processing business based on pesantren at Situbondo Regency

\begin{tabular}{|c|c|c|c|c|}
\hline \multirow[b]{2}{*}{ Code } & \multirow[b]{2}{*}{ Internal Factor } & \multicolumn{2}{|c|}{ Average } & \multirow[b]{2}{*}{$\begin{array}{c}\text { Total } \\
\text { (c) }\end{array}$} \\
\hline & & $\begin{array}{l}\text { Score } \\
\text { (a) }\end{array}$ & $\begin{array}{l}\text { Weight } \\
\text { (b) }\end{array}$ & \\
\hline & Strengths $(S)$ & & & \\
\hline S1 & 1. Social capital of pesantren & 0.067 & 4.0 & 0.268 \\
\hline $\mathrm{S} 2$ & 2. Pesantren market is potential & 0.069 & 4.0 & 0.276 \\
\hline S3 & 3. Pesantren have direct consumers & 0.045 & 3.5 & 0.158 \\
\hline S4 & $\begin{array}{l}\text { 4. The noble values of pesantren such as honesty, } \\
\text { independence, and sincere service }\end{array}$ & 0.038 & 3.5 & 0.133 \\
\hline S5 & $\begin{array}{l}\text { 5. Militancy/loyalty of the pesantren community to } \\
\text { pesantren is high relatively }\end{array}$ & 0.048 & 3.8 & 0.182 \\
\hline S6 & $\begin{array}{l}\text { 6. The brand image of pesantren products will become more } \\
\text { values }\end{array}$ & 0.043 & 3.0 & 0.129 \\
\hline S7 & $\begin{array}{l}\text { 7. Pesantren have millennial human resources (young and } \\
\text { productive) as workers }\end{array}$ & 0.032 & 2.8 & 0.090 \\
\hline S8 & 8. Labor costs are cheap relatively & 0.054 & 3.0 & 0.162 \\
\hline \multirow[t]{3}{*}{ S9 } & $\begin{array}{l}\text { 9. There are a relationship pesantren with pesantren and } \\
\text { pesantren with the community }\end{array}$ & 0.054 & 3.2 & 0.173 \\
\hline & Total & 0,450 & & 1.285 \\
\hline & Weaknesses $(W)$ & & & \\
\hline W1 & 1. Management is still traditional and done incidentally & 0.077 & 3.8 & 0.293 \\
\hline W2 & 2. Dependency on kyai is high relatively & 0.082 & 4.0 & 0.328 \\
\hline W3 & 3. Team work ability is relatively low & 0.063 & 3.8 & 0.239 \\
\hline W4 & 4. Work ethic is low relatively & 0.058 & 3.5 & 0.203 \\
\hline W5 & $\begin{array}{l}\text { 5. Finance and access to finance institution is low relatively } \\
\text { 6. Dependence on other parties is high relatively }\end{array}$ & 0.032 & 2.5 & 0.080 \\
\hline W6 & 7. Business ability is relatively low & 0.032 & 2.5 & 0.080 \\
\hline W7 & 8. Relationship with the government in the economic field & 0.022 & 2.7 & 0.059 \\
\hline W8 & $\begin{array}{l}\text { is still low relatively } \\
\text { 9. The business climate in pesantren has not well }\end{array}$ & 0.037 & 3.0 & 0.111 \\
\hline W9 & 10. Most pesantren do not yet have business and economy & 0.047 & 3.8 & 0.179 \\
\hline W10 & institutions & 0.056 & 3.5 & 0.196 \\
\hline \multirow[t]{3}{*}{ W11 } & $\begin{array}{l}\text { 11. Not yet experienced in managing of business } \\
\text { agroindustry } \\
\text { Total }\end{array}$ & 0.044 & 3.5 & 0.154 \\
\hline & & 0.550 & & 1.922 \\
\hline & Total (Strengths + Weaknesses) & 1.00 & & 3.049 \\
\hline
\end{tabular}

Source: Data processed, 2018 
Table 2. External factors analysis on the planning and development of fishery product processing business based on pesantren at Situbondo Regency

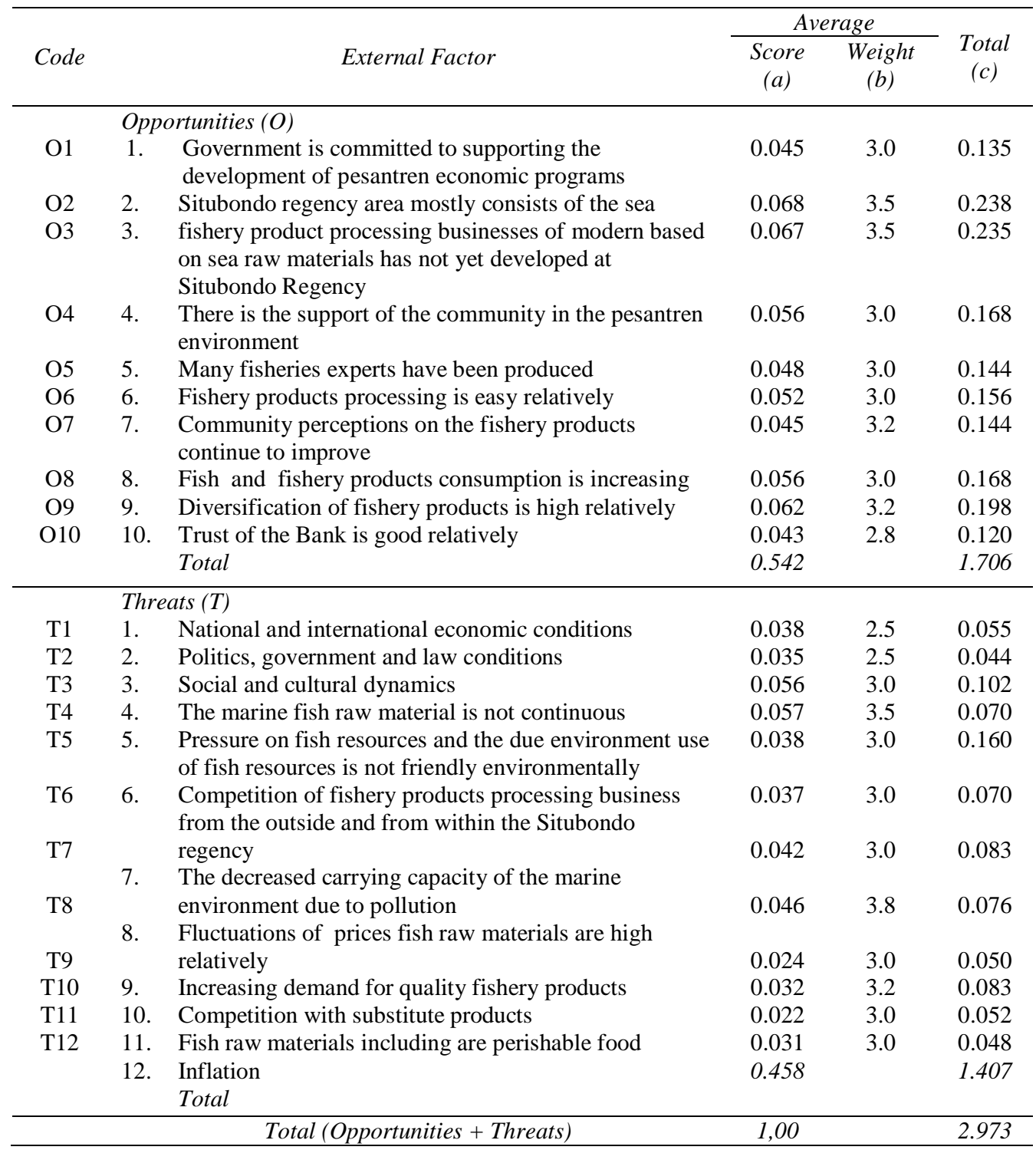




\section{Determining the Organizational Position}

Organization position on the planning and development of fishery product processing businesses based on pesantren at Situbondo regency is determined based on the results of quadrant coordinates :

$$
\begin{aligned}
& \mathrm{d}=\mathrm{x}=\Sigma \mathrm{S}-\Sigma \mathrm{W}=1.285-1.922=-0.352 \\
& \mathrm{e}=\mathrm{y}=\Sigma \mathrm{O}-\Sigma \mathrm{T}=1.706-1.407=0.299
\end{aligned}
$$

organizational position on the planning and development of fishery product processing businesses based on pesantren at Situbondo regency is in Quadrant III (negative, positive). This organization position is weak but has an opportunity. The strategy recommended is Change of Strategy, meaning that the organization is advised to change the before strategy. Because the old strategy is feared of difficult to be able to capture of existing opportunities. In this case, even though pesantren at Situbondo Regency has great potential in the development of fishery product processing business, but the pesantren also has great internal weaknesses. If these weaknesses are not addressed, the pesantren will not be able to capture these great opportunities.

\section{Formulating the Organizational Strategies}

Formulating of planning and development strategies on the fishery product processing businesses based on pesantren at Situbondo regency is based on the analysis results of all factors of internal (Table 1) and external (Table 2.). In Table 3 is presented of alternative strategies for the planning and development of fishery product processing businesses based on pesantren at Situbondo Regency:

1. Managing the market potential of pesantren

2. Improving the system and management of pesantren organization

3. Improving the quality of pesantren human resources

4. Developing the system of fishery product processing business is professionally

5. Strengthing the character and adaptability of pesantren

6. Developing the system of sustainable fishery product processing business

7. Developing superior fishery processed products based on pesantren

8. Improving the institutional performance of pesantren 
Table 3. Matrix of planning and development strategy of fishery products processing based on pesantren at Situbondo Regency

\begin{tabular}{|c|c|c|}
\hline Internal Factor & $\begin{array}{c}\text { Strengths }(\mathrm{S}) \\
\mathrm{S} 1, \mathrm{~S} 2, \mathrm{~S} 3, \mathrm{~S} 4, \mathrm{~S} 5, \mathrm{~S} 6, \mathrm{~S} 7, \mathrm{~S} 8, \mathrm{~S} 9\end{array}$ & $\begin{array}{c}\text { Weaknesses }(W) \\
\text { W1, W2, W3, W4, W5, W6, W7, } \\
\text { W8, W9, W10, W11 }\end{array}$ \\
\hline $\begin{array}{l}\text { Opportunities }(O) \\
\text { O1, O2, O3, O4, O5, } \\
\text { O6, O7, O8, O9, O10 }\end{array}$ & 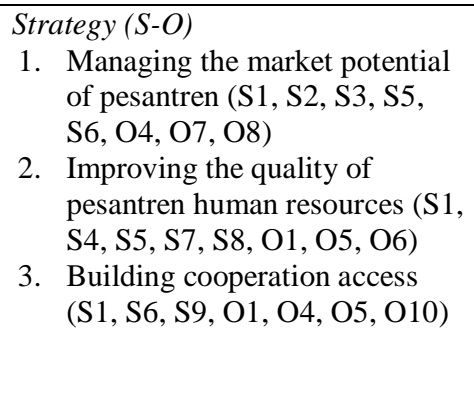 & $\begin{array}{l}\text { Strategy }(\mathrm{W}-\mathrm{O}) \\
\text { 1. Improving the system and } \\
\text { management of pesantren } \\
\text { organization (W1, W2, W3, } \\
\text { W4, W6, W7, W8, O1, O4) } \\
\text { 2. Developing the system of } \\
\text { fishery product processing } \\
\text { business is professionally (W1, } \\
\text { W2, W3, W4, W5, W9, W10, } \\
\text { W11, O2, O3, O5, O6, O7, O8, } \\
\text { O9, O10) }\end{array}$ \\
\hline $\begin{array}{l}\text { T1, T2, T3, T4, T5, T6, } \\
\text { T7, T8, T9, T10, T11, } \\
\text { T12 }\end{array}$ & 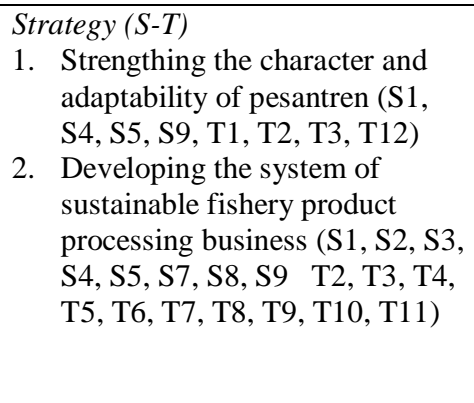 & 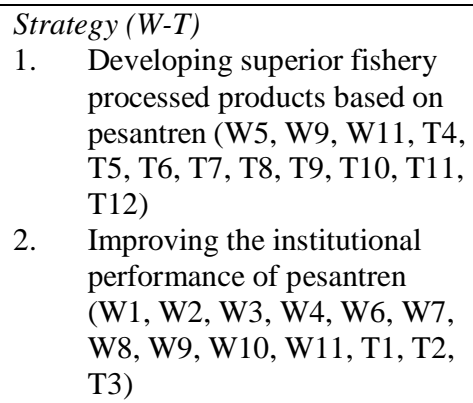 \\
\hline
\end{tabular}

Source: Data processed, 2018

\subsection{QSPM Analysis}

The analytical tool used to determine the priority strategy on the planning and development of fishery product processing business based on pesantren at Situbondo Regency is QSPM

Alternative strategies with the highest TAS value are strategies that need to be prioritized to be applied first. Priority strategies on the planning and development of fishery product processing business based on pesantren at Situbondo Regency can be seen in Table 4. 
Table 4. Strategy Priority on the planning and development of fishery product processing business based on pesantren at Situbondo Regency

\begin{tabular}{|c|c|c|c|}
\hline No & Alternative Strategies & Total TAS & Rating \\
\hline 1 & Managing the market potential of pesantren & 7.704 & 3 \\
\hline 2 & $\begin{array}{l}\text { Improving the system and management of pesantren } \\
\text { organization }\end{array}$ & 7.759 & 2 \\
\hline 3 & Building cooperation access & 6.135 & 8 \\
\hline 4 & Improving the quality of pesantren human resources & 7.821 & 1 \\
\hline 5 & $\begin{array}{l}\text { Developing the system of fishery product processing business is } \\
\text { professionally }\end{array}$ & 7.458 & 4 \\
\hline 6 & Strengthing the character and adaptability of pesantren & 6.548 & 6 \\
\hline 7 & $\begin{array}{l}\text { Developing the system of sustainable fishery product processing } \\
\text { business }\end{array}$ & 6.114 & 9 \\
\hline 8 & $\begin{array}{l}\text { Developing superior fishery processed products based on } \\
\text { pesantren }\end{array}$ & 7.436 & 5 \\
\hline 9 & Improving the institutional performance of pesantren & 6.168 & 7 \\
\hline
\end{tabular}

In Table 4 it can be seen that the priority strategy that must be first applied on the planning and development of fishery product processing business based on pesantren at Situbondo Regency is improving the quality of pesantren human resources. The interviews results with experts show that the low quality of human resources on the pesantren is soft skills aspect which includes honesty, mindset, work ethic, work culture, and human resource management [13].

Improving the quality of pesantren human resources can be done by building the work culture is good, effectiveness, innovation, loyalty, and productivity. Building the work culture can be done by 1) providing the work motivation, 2) building the attitudes and commitment to work, 3) influencing the leadership processes is oriented to employee (humanistic leadership), 4) communicating is well, 5) building the good organizational structure, 6) improving the employee performance, 7) improving the organizational productivity (through managers who have a philosophy of competitiveness \& comparability), 8) creating the job satisfaction, 9) fostering the sense of belonging and responsibility, 10) creating the work climate is conducive [14]. The success in improving the quality of pesantren human resources is expected to facilitating the implementation of next priority alternative strategies.

\section{Conclusions}

There are nine strategies on the planning and developing of fishery product processing businesses based on pesantren at Situbondo Regency. Nine strategies based on priority scale include (1) improving the quality of pesantren human resources, (2) improving the system and management of pesantren organization, (3) managing the market potential of pesantren, (4) developing the system of fishery product processing business is professionally, (5) developing the superior fishery processed products based on pesantren, (6) strengthing the character and adaptability of pesantren, (7) improving the institutional performance of pesantren, (8) Building the cooperation access, (9) developing the system of sustainable fishery product processing business. 
Acknowledgments. The author would like to thank KHR. Azaim Ibrahimy as the Head of Pesantren Salafiyah Syafi'iyah Situbondo Indonesia for moral support for this research

\section{References}

[1] BPS. Situbondo Dalam Angka Tahun 2017 (2018)

[2] D. Howara. Strategi Pengembangan Pengolahan Hasil Perikanan di Kabupaten

Donggala. vol. 17. no. 3. pp. 75-81 (2013)

[3] R. B. S. Salampessy, A. Permadi and J. Haluan. Kajian Analisis Pengembangan Pengolahan

Hasil Perikanan Di Kabupaten Serang. vol. 1. no. 1. pp. 9-16 (2012)

[4] S. Zulfiqar Bin Tahir. The Attitude of Santri and Ustadz Toward Multilingual Education at Pesantren. Int. J. Lang. Linguist. vol. 3. no. 4. p. 210 (2015)

[5] Sutomo, S. Kanto, D. Wisadirana and S. Mu'adi. The Social Capital Of Pesantren Rakyat Community In The Development. vol. 9, no. 4. pp. 78-93 (2018)

[6] N. Khusniyah. Management by Inspiration : Implementation of Transformational Leadership on Business at Pondok Pesantren *) Sunan Drajat. Procedia - Soc. Behav. Sci. vol. 115. pp. 79-90 (2014)

[7] N. Setyowati, W. Rahayu, and D. Ishartani. Development of Tuna Processed Business in Pacitan District, Indonesia. Aquat. Procedia. vol. 7. pp. 160-165 (2016)

[8] L. Van Den Abeele, T. Smets, A. Derden, D. Huybrechts, and F. Nevens. Feasibility study for the food processing industry in Flanders ( Belgium ) to become water neutral by 2030. J. Clean. Prod. vol. 141.pp. 1376-1390 (2017)

[9] T. Bjørndal, A. Brasão, J. Ramos, and A. Tusvik. Fish processing in Portugal : An industry in expansion. vol. 72.pp. 94-106 (2016)

[10] D. Wijayanto. Fisheries Development Strategies of Biak Numfor Regency, Indonesia. Aquat. Procedia. vol. 7. pp. 28-38 (2016)

[11] G. W. Lailossa, K. B. Artana, and N. Pujawan. Model of strategy quality improvement of tuna and other species in the cold chain system ( FUZZY expert systems approach ). vol. 9. no. 5. pp. 1154-1166 (2016)

[12] M. Fridah, S. Theuri, F. M. Mwirigi, and P. G. Namusonge. Strategic Management Determinants of Value Addition in the Sea Food Processing Sub-Chain : A Survey of Industrial Fish Processors in Kenya. vol. 2. no. 6. pp. 53-62. (2014)

[13] S. N. Azizah. Pengelolaan Unit Usaha Pesantren Berbasis Ekoproteksi. vol. IX. no. 1. pp. 103-115 (2014)

[14] A. Muhith. Quality Culture Of Islamic Boarding School. vol. 6. no. 10. pp. 25-37 (2018) 